\title{
ANTIBODIES RECOGNIZING GLOBULAR DOMAIN OF CIq - CURRENT VIEW ON THE ASSOCIATION BETWEEN LUPUS NEPHRITIS ACTIVITY AND ANTI-gClq AUTOANTIBODIES
}

\author{
Maria Radanova ${ }^{1}$, Vishnya Stoyanova ${ }^{2}, K$ amelia Bratoeva ${ }^{3}$, Vasil Vasilev ${ }^{4}$, \\ Valentin Ikonomov ${ }^{5}$, Diana Ivanova ${ }^{1}$ \\ ${ }^{1}$ Department of Biochemistry, Molecular Medicine and Nutrigenomics, \\ Medical University of Varna \\ ${ }^{2}$ Department of Chemistry, Biochemistry, Physiology, and Pathophysiology, Sofia University \\ ${ }^{3}$ Department of Physiology and Pathophysiology, Medical University of Varna \\ ${ }^{4}$ Clinic of Nephrology, University Hospital - "Tzaritza Ioanna - ISUL", \\ Medical University - Sofia \\ ${ }^{5}$ Clinic of Nephrology, Acute and Peritoneal Dialysis, Apheresis and Transplantation, \\ University Hospital - "St. Marina", Medical University of Varna
}

\begin{abstract}
INTRODUCTION: Lupus nephritis (LN) is a serious complication of the systemic lupus erythematosus (SLE). Anti-Clq antibodies correlate with the occurrence and high clinical activity of LN, especially proliferative $\mathrm{LN}$. The first reported anti-Clq antibodies recognized autoepitopes within a collagen-like region (CLR) of C1q. Recently we have found autoantibodies against globular Clq domain (gC1q antibodies) in LN patients. The aim of the present study was to evaluate the potential pathological consequences of the presence of anti-gClq antibodies in LN.

MATERIAL AND METHODS: The recombinant globular head region of the three chains of C1q -A, -B and -C were expressed in $E$. coli BL21 and purified. Anti-C1q, anti-gClq autoantibodies, complement proteins - C1q, C4, C3 and IgG-, IgM-CICs levels were screened by ELISA in 53 sera from LN patients. Sera from 196 normal controls served as controls.

RESULTS: We found that patients positive for anti-B-gClq antibodies presented with significantly lower serum $\mathrm{C} 4$ levels than patients positive for anti-A and anti-C-gClq antibodies $(\mathrm{p}=0.014)$ and with significantly lower levels of $\mathrm{C} 3$ than patients positive for anti-A and anti-C-gClq antibodies and patients without anti-

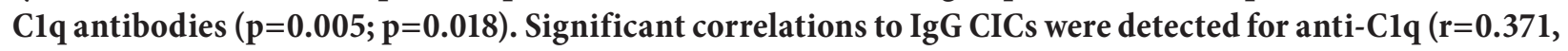
$\mathrm{p}=0.001)$ and anti-B-gC1q antibodies $(\mathrm{r}=0.431, \mathrm{p}=0.003)$.
\end{abstract}

Address for correspondence:

Maria Atanasova Radanova

55 Marin Drinov St.

Department of Biochemistry, Molecular Medicine and

Nutrigenomics, Medical University of Varna

9002, Varna

e-mail:maria.radanova@gmail.com

Received: November 8, 2015

Accepted: February 2, 2016
CONCLUSIONS: These findings suggest that the binding of anti-B-gClq autoantibodies with Clq may possibly trigger mechanical stress and induce a structural change within the CLR domain of Clq, compatible with $\mathrm{Clr}$-C1s complement activation in the fluid phase.

Keywords: anti-C1q autoantibodies, anti-gC1q autoantibodies, lupus nephritis 
Antibodies Recognizing Globular Domain of C1q - Current View on the Association between Lupus Nephritis Activity ...

\section{INTRODUCTION}

Lupus nephritis (LN) is a major and severe complication of the systemic lupus erythematosus (SLE) with kidney inflammation and flare. SLE is characterized by the production of various autoantibodies (more than 100 different types of autoantibodies) and immune complexes deposition, which activate the complement. Autoantibodies to Clq, the first subcomponent of $\mathrm{C} 1$ in the classical complement activation, are a hallmark of renal involvement and a predictive marker for a flare of LN (1-11). Many research groups put a lot of effort to understand the initial events that trigger autoimmunity against $\mathrm{Clq}$, the role of anti-Clq autoantibodies in the pathogenesis of lupus nephritis and the consequence of the interactions between these serum molecules. However, by now only several hypotheses are presented and many questions remain unclear and the findings are not fully characterized yet.

Clq is the first component of the classical pathway of the complement activation and its main functions are to clear apoptotic cells and immune complexes (ICs). Clq, a major linking molecule between innate and adaptive immunity, also regulates inflammatory mechanisms at cellular and molecular levels (12-16). Clq is a hexameric molecule. Its quaternary structure contains an $\mathrm{N}$-terminal triple-helical collagen-like region (CLR) and $C$-terminal heterotrimeric globular head domain (gClq). The gClq domain is composed of $\mathrm{C}$-terminal halves of the $\mathrm{A}$ (ghA), B (ghB) and C (ghC) chains. The Clq molecule $(460 \mathrm{kDa})$ is composed of 18 polypeptide chains (6A, 6B, and 6C) (17).

Anti-C1q autoantibodies are mainly against neoepitopes within the CLR of human Clq (4, 7, 18, 19). Recently we have shown that epitopes within the $\mathrm{gClq}$ domain of the Clq molecule may be targeted by anti-Clq autoantibodies (20-22), possibly with functional consequences (22). We found that anti-ghB, but not anti-ghA and anti-ghC autoantibodies, markedly inhibited Clq interaction with IgG as well as with CRP, which suggested that the antighB autoantibodies might partially induce acquired functional Clq deficiency (22). More importantly, the role of these autoantibodies recognizing different epitopes in the large C1q molecule is to be understood, when and how they appear in the serum and mune response and pathology. Therefore, the aim of this study was to evaluate the potential pathological consequences of the presence of anti-gClq antibodies in lupus nephritis.

\section{MATERIAL AND METHODS}

\section{Volunteers}

The LN serum samples were collected from patients with biopsy-proven lupus nephritis from the Clinic of Nephrology, University Hospital "Tzaritza Ioanna - ISUL" - Sofia. The analysed cohort included 46 (86.79\%) women and 7 (13.21\%) men with a mean age of $40( \pm 13.77)$ years. All patients fulfilled at least 4 of 11 of the American College of Rheumatology classification criteria for SLE (23), and the diagnosis of lupus nephritis was based on clinical and laboratory parameters including proteinuria, urinary sediment, creatinine level, and erythrocyte sedimentation rate. The disease activity was evaluated by SLEDAI (SLE Disease Activity Index). Inclusion criteria were defined as proteinuria $500 \mathrm{mg} / 24 \mathrm{hr}$ or higher in the last 10 days, erythrocyturia as $8 \mathrm{RBC}$ per microliter or higher, renal dysfunction as any increase in creatinine value at any time in the history, and renal involvement as any of the two above variables.

The presence of antinuclear antibodies (ANAs) and anti-dsDNA autoantibodies were detected by double immunodiffusion assays and indirect immunofluorescence in University Hospital "Tzaritza Ioanna - ISUL" - Sofia.

The group of healthy volunteers included 118 $(60.20 \%)$ women and $78(39.80 \%)$ men with a mean age of $46( \pm 14.36)$ years.

The study had the approval of the Ethics Review Board of Medical University of Varna and each patient and healthy volunteer signed a consent form of enrolment.

\section{ELISA for Determination of Serum Comple- ment Proteins Levels}

The concentrations of $\mathrm{Clq}, \mathrm{C} 4$ and $\mathrm{C} 3$ antigens in serum were measured by means of a double-ligand ELISA as described previously (22). Normal values, established with pooled plasma from 196 healthy blood donors, ranged between $59-178 \mu \mathrm{g} / \mathrm{ml}, 84-$ $396 \mu \mathrm{g} / \mathrm{ml}$ and $612-1444 \mu \mathrm{g} / \mathrm{ml}$ (mean $\pm 2 \mathrm{SD}$ ) for C1q, C4 and C3, respectively. 
Maria Radanova, Vishnya Stoyanova, Kamelia Bratoeva et al.

\section{CH50}

$\mathrm{CH} 50$ test (samples plasma) was used as a functional measurement of the activity of the whole complement pathway from classical pathway activation. $\mathrm{CH} 50$ was determined according to standard procedure (24). Results were expressed as a percentage of the $\mathrm{CH} 50$ of a reference plasma pool obtained from 196 healthy blood donors. Normal values for $\mathrm{CH} 50$ were $53-146 \%$ ( $\pm 2 \mathrm{SD})$.

Expression and Purification of the Recombinant Globular Head Regions of the Three Chains of C1q

The recombinant globular head regions of the A chain (ghA, residues 88-223), the B chain (ghB, 90226), and the $C$ chain (ghC, 87-217) were expressed as fusion proteins linked to the maltose-binding protein (MBP) in Escherichia coli BL21 and purified, as described previously (17).

ELISA for Detection of Anti-C1qAutoantibodies Levels

Anti-Clq autoantibody levels were measured in human serum samples under $0.75 \mathrm{M} \mathrm{NaCl}$ conditions as described previously $(21,25)$. Values were expressed in terms of fold increase compared to the pooled normal human serum (NHS) from 196 healthy volunteers (norm=1).

ELISA for Detection of IgG- and IgM-containing Circulating Immune Complexes

Serum levels of IgG- or IgM-containing circulating immune complexes (CICs) levels were determined using the same principle, as ELISA for antiClq antibodies, except that the plates were incubated with patients' sera, diluted 1:100 in PBS/0.15 M $\mathrm{NaCl}$ (25). Values were expressed in terms of fold increase compared to the pooled normal human serum (NHS) from 196 healthy volunteers.

\section{Statistical Analysis}

Statistical analysis was carried out using software GraphPad Prism 5.01. Quantitative data were expressed as mean $\pm S D$. For comparison between groups of patients and of healthy volunteers, the Mann-Whitney $U$ test for continuous variables for 2-group comparisons was used. The Spearman Correlation was used to analyse the correlations. $P$ values less than 0.05 were considered significant. All tests were 2-tailed.

\section{RESULTS}

Main Complement Features and Levels of Anti-C1q, Anti-gC1q Autoantibodies and Circulating Immune Complexes (CICs) in Sera of Lupus Nephritis Patients

Measurement of complement hemolytical activity, levels of serum Clq, C4 and C3 concentration, the presence of anti-Clq, ANA, anti-dsDNA antibodies, and circulating immune complexes (CICs) were used to monitor the disease. Three patients had low levels of $\mathrm{Clq}$, $\mathrm{CH} 50$ and $\mathrm{C} 4$. C1q binding IgG-CICs were present in these sera. Only one serum of them was seropositive for anti-Clq autoantibodies. We found low levels of $\mathrm{Clq}$ and $\mathrm{CH} 50$ in five different sera with detected presence of Clq-IgG-CICs. Three of them were seropositive for anti-Clq antibodies and for anti-gClq autoantibodies against A- and/or C-chains of C1q. 17 out of 53 patients (32.08\%) were positive for anti-Clq autoantibodies. Nevertheless, 33.96\% $(18 / 53)$ were positive for anti-gClq autoantibodies. 10 out of $53 \mathrm{LN}$ patients (18.87\%) were seropositive only for anti-A and/or anti-C-gClq. Eight patients from all 53 (15.09\%) were positive predominantly for anti-B-gClq autoantibodies and only one was positive also for anti-Clq antibodies. In $43.40 \%$ of lupus ne-
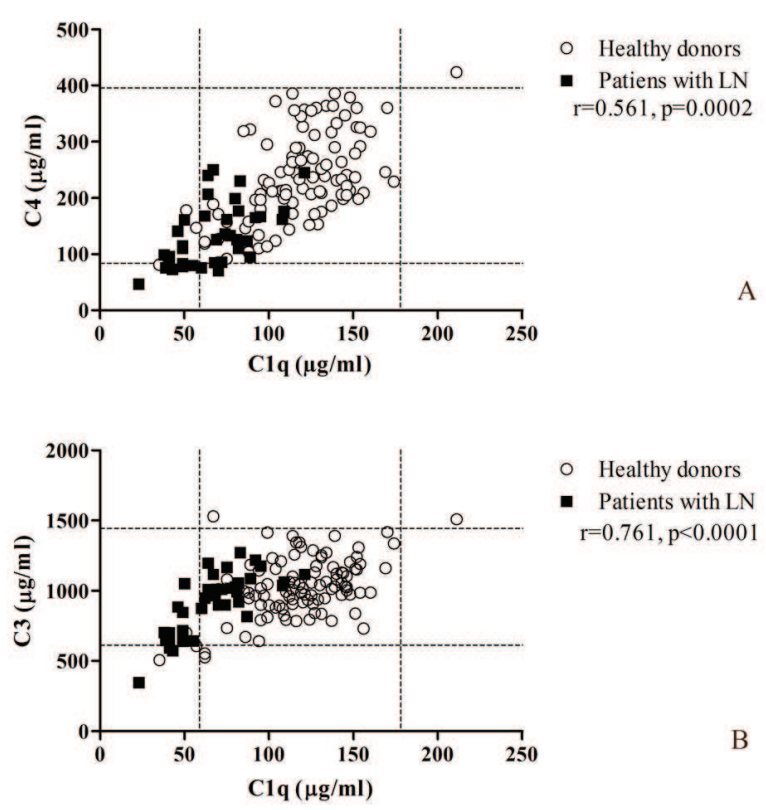

Fig. 1. Correlation between serum levels of C4 and C1q in lupus nephritis patients and normal controls (A.). Correlation between serum levels of $C 3$ and $C 1 q$ in lupus nephritis patients and normal controls (B.). 
phritis patients (23/53) we did not find anti-Clq and anti-gClq antibodies. We detected that $60.00 \%$ of the patients were positive for ANA and $44.00 \%$ of the
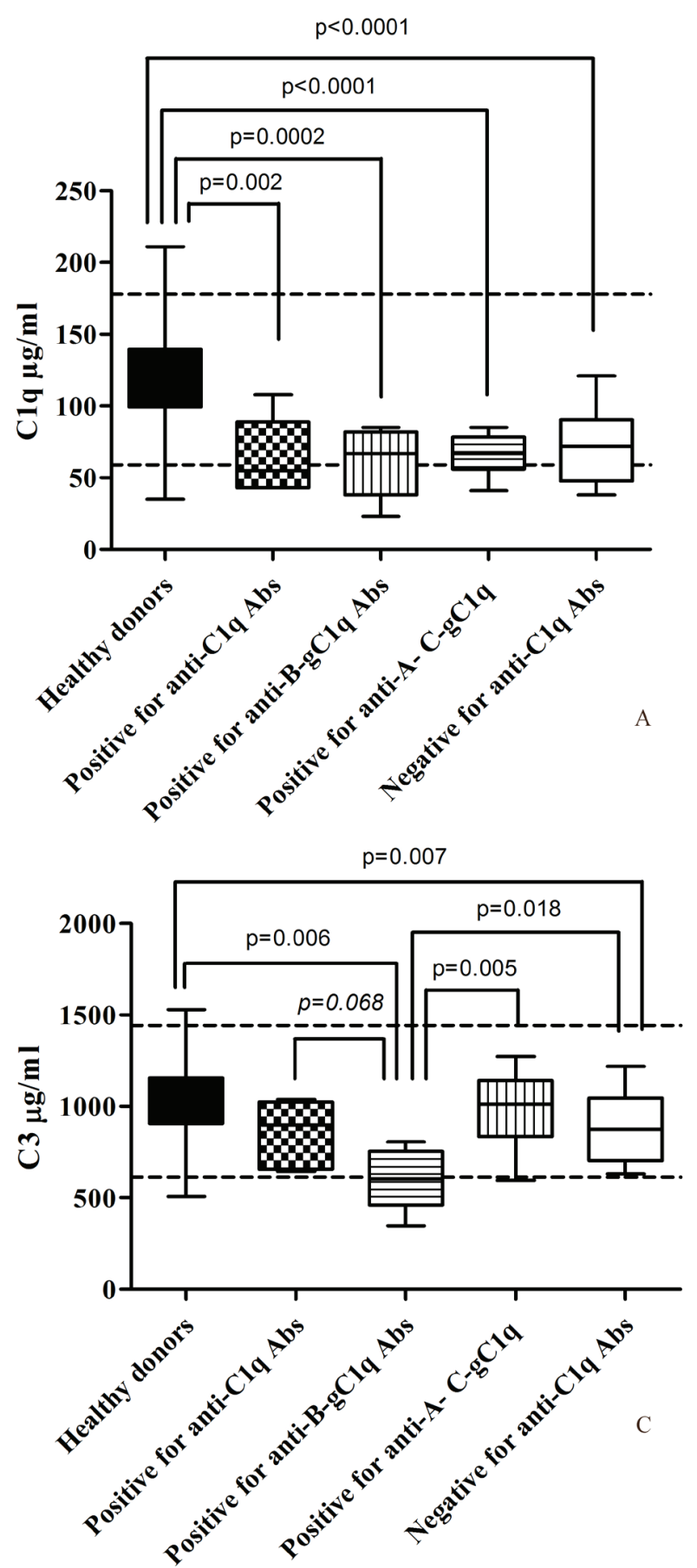

patients were positive for anti-dsDNA autoantibodies. The levels of Clq significantly correlated with C4

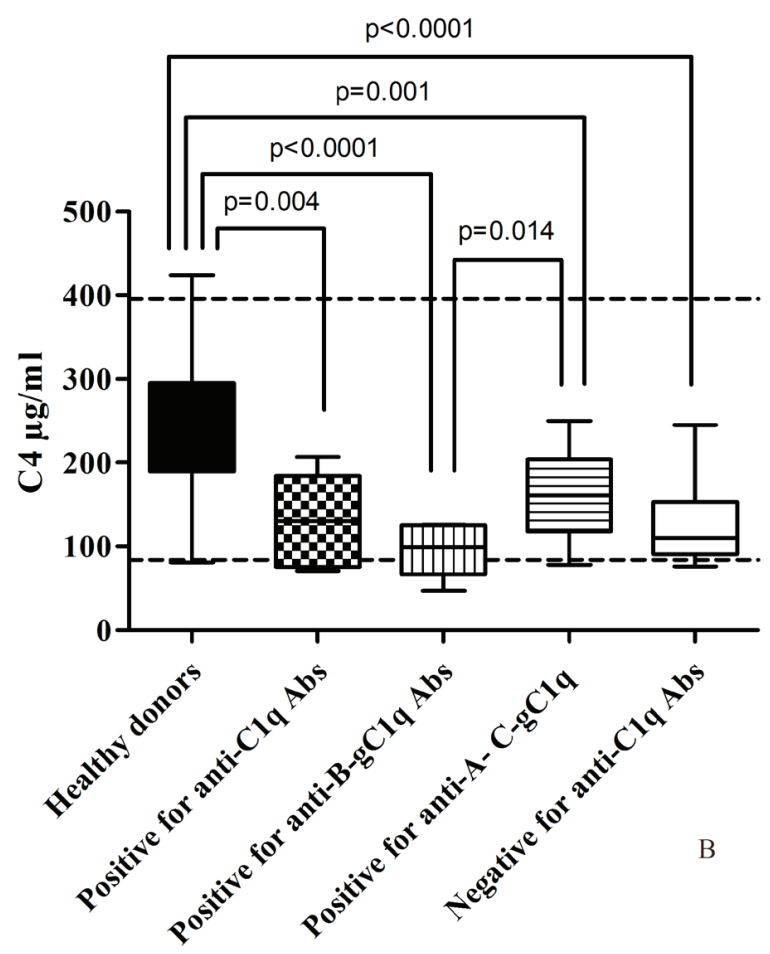

Fig. 2. Comparison of serum C1q (A.), C4 (B.) and C3 (C.) levels in normal controls and in patients: seropositive for antiC1q antibodies; seropositive for anti-B-gC1q antibodies; seropositive for anti-A and anti-C-gC1q antibodies and negative for anti-C1q antibodies. The horizontal line indicates the cut-off value. 
Maria Radanova, Vishnya Stoyanova, Kamelia Bratoeva et al.

$(\mathrm{r}=0.561, \mathrm{p}=0.0002)$ and with $\mathrm{C} 3(\mathrm{r}=0.561, \mathrm{p}<0.0001)$ in LN patients (Fig. 1, A. and B.)

Association between the Levels of C1q and the Presence of Anti-C1q and Anti-gC1q Antibodies in Lupus Nephritis Sera

All lupus nephritis patients were divided into four groups - positive for anti-Clq antibodies, but negative for anti-gClq antibodies (12); positive for anti-B-gClq antibodies (8, out of which 7 positive also for anti-Clq antibodies); positive for anti-A and/ or anti-C-gClq antibodies (10, out of which 3 positive also for anti-C1q antibodies) and negative for antiClq antibodies (23). Serum C1q levels in these groups and normal controls were compared (Fig. 2A). All patients sera from the four groups presented with significantly lower levels of serum Clq than the healthy donors $(120.00 \mu \mathrm{g} / \mathrm{ml}$ vs. $55.00 \mu \mathrm{g} / \mathrm{ml}, \mathrm{p}=0.002 ; 67.00$ $\mu \mathrm{g} / \mathrm{ml}, \mathrm{p}=0.0002 ; 67.00 \mu \mathrm{g} / \mathrm{ml}, \mathrm{p}<0.0001 ; 72.00 \mu \mathrm{g} /$ $\mathrm{ml}, \mathrm{p}<0.0001$ in groups).

Association between the Serum C4 Levels and the Presence of Anti-C1q and Anti-gC1q Antibodies in Lupus Nephritis Sera

Serum C4 levels in the groups: positive for anti-Clq antibodies; positive for anti-B-gClq antibodies; positive for anti-A and anti-C-gClq antibodies and negative for anti-Clq antibodies, were analysed and compared with the normal controls (Fig. 2B). We found significantly lower serum C4 levels in all four groups of lupus nephritis patients in comparison with the levels in the healthy donors $(231.00 \mu \mathrm{g} /$ $\mathrm{ml}$ vs. $130.00 \mu \mathrm{g} / \mathrm{ml}, \mathrm{p}=0.004 ; 99.00 \mu \mathrm{g} / \mathrm{ml}, \mathrm{p}<0.0001$; $161.00 \mu \mathrm{g} / \mathrm{ml}, \mathrm{p}=0.001 ; 110.00 \mu \mathrm{g} / \mathrm{ml}, \mathrm{p}<0.0001$ in groups). Patients sera positive for anti-B-gClq anti-
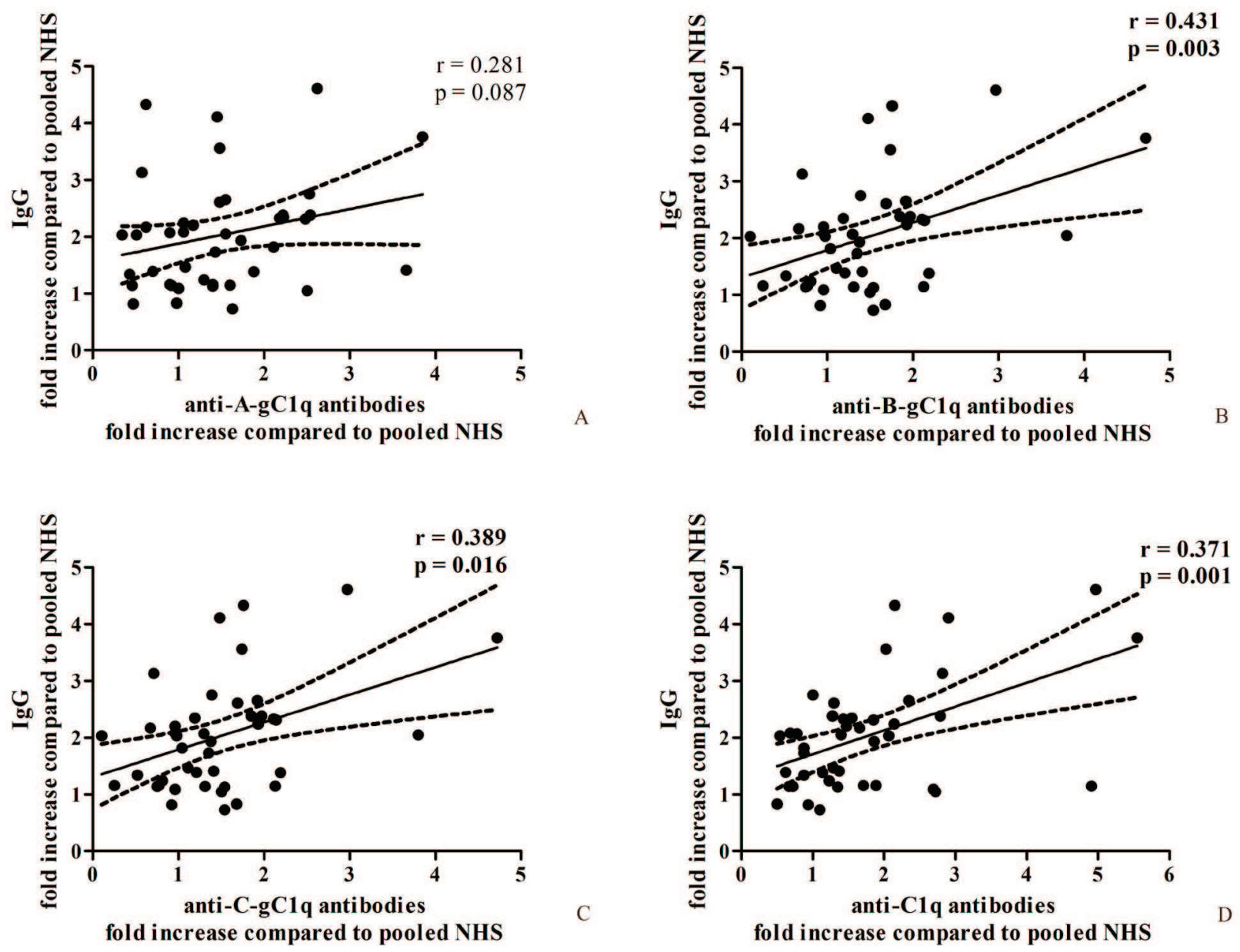

Fig. 3. Correlation between serum levels of anti-A-gC1q antibodies (A.), anti-B-gC1q antibodies (B.), anti-C-gC1q antibodies (C.), anti-C1q antibodies (D.) and IgG CIC in lupus nephritis patients. 
bodies presented with significantly lower serum C4 levels than patients sera positive for anti-A and anti-C-gClq antibodies $(120.00 \mu \mathrm{g} / \mathrm{ml}$ vs. $161.00 \mu \mathrm{g} / \mathrm{ml}$, $\mathrm{p}=0.014$ ).

Association between the Serum C3 Levels and the Presence of Anti-C1q and Anti-gC1q Antibodies in Lupus Nephritis Sera

Our analyses detected lower serum C3 levels in patients sera positive for anti-B-gClq antibodies and negative for anti-Clq antibodies compared to the normal controls $(1014 \mu \mathrm{g} / \mathrm{ml}$ vs. $634 \mu \mathrm{g} / \mathrm{ml}, \mathrm{p}=0.006$; $875 \mu \mathrm{g} / \mathrm{ml}, \mathrm{p}=0.007)$. Patients positive for anti-B$\mathrm{gClq}$ antibodies presented with significantly lower levels of C3 in serum than patients positive for anti-A and anti-C-gClq antibodies and patients without anti-Clq antibodies $(634 \mu \mathrm{g} / \mathrm{ml}$ vs. $1013 \mu \mathrm{g} / \mathrm{ml}$, $\mathrm{p}=0.005 ; 875 \mu \mathrm{g} / \mathrm{ml}, \mathrm{p}=0.018)$. The serum C3 levels of patients seropositive for anti-B-gClq antibodies were also lower than the $\mathrm{C} 3$ levels in positive for anti-Clq antibodies patients $(634 \mu \mathrm{g} / \mathrm{ml}$ vs. $851 \mu \mathrm{g} / \mathrm{ml}$, $\mathrm{p}=0.068)($ Fig. 2C).

Association between the Levels of ANA and/or Anti-ds DNA Antibodies and Presence of Anti-C1q and Anti-gC1q Antibodies in Lupus Nephritis Sera

The cohort of lupus nephritis patients were divided into two groups - positive for ANA and negative for ANA. Both groups were analysed for the presence of anti-Clq and/or anti-gClq antibodies. We did not find any significant association between ANA and anti-A-gClq, anti-B-gClq, anti-C-gClq and anti-Clq antibodies. No significant association between anti-ds DNA antibodies and anti-gClq and/ or anti-Clq antibodies was found in the two groups - positive and negative for anti-dsDNA antibodies.

Correlations between the Presence of Anti-C1q and Anti-gC1q Antibodies and Some Markers of Lupus Nephritis Activity.

We assessed the correlation of anti-C1q and anti-gClq antibody with several serologic markers of disease activity such as levels of C1q, C4, C3, IgGand IgM-CICs. For anti-Clq antibodies there was only a trend for negative correlations with $\mathrm{Clq}$ and C3 levels. Similarly, a tendency for negative correlation between anti-B-gClq antibodies and $\mathrm{C} 3$ was observed. For anti-B-gClq, anti-C-gClq and anti$\mathrm{Clq}$ antibodies there were significant correlations to IgG CICs ( $r=0.431, p=0.003 ; r=0.389, p=0.016$ and $\mathrm{r}=0.371, \mathrm{p}=0.001)$ and for anti-A-gClq antibodies to IgG CICs - a correlational trend $(\mathrm{r}=0.281, \mathrm{p}=0.087)$ was found (Fig. 3). The levels of IgM CICs decreased in accordance with the increase of anti-Clq antibodies $(r=-0.238, p=0.051)$.

\section{DISCUSSION}

Several studies have shown that anti-Clq autoantibodies correlate with the occurrence and high clinical activity of LN, especially proliferative LN $(2,4,7,9,10)$. The increasing of anti-Clq antibodies was shown to predict renal relapse within 6 months $(1,26)$. On the other side, Katsumata et al., (2011) and Trad et al., (2013) recently revealed a lack of specific association of anti-C1q antibodies with active and also with proliferative nephritis $(27,28)$. Gunnarsson et al., (2002) and Marto et al., (2005) also did not find differences in levels or prevalence of anti-Clq antibodies between patients with proliferative and patients with non-proliferative form of $\operatorname{LN}(5,6)$. These few studies contradict the widespread allegation that anti-Clq antibodies are pathogenic.

Flierman and Daha (2007) suggested a hypothesis to explain the role of anti-Clq antibodies in the development of LN (29). According to their model, the presence of anti-Clq antibodies seems to be a necessary, but not sufficient, condition for the development of LN and is associated with Clq deposition and nucleosomes containing CICs accumulation in the glomerular basement membrane. The subsequent local activation of complement leads to renal damage during inflammatory response and hypocomplementemia in serum is indication for this (29). We suggested that probably the pathological role of anti-Clq antibodies was not as much in the activation as in the amplification of prolonged activated complement attack.

Anti-Clq autoantibodies may affect the physiological role of $\mathrm{Clq}$ indirectly by elimination of the available Clq in the circulation. Moreover, researchers have demonstrated a negative correlation between anti-Clq antibodies and plasma $\mathrm{Clq}$ (30). Chen et al., (2002) found that serum anti-Clq antibody levels were higher in $\mathrm{LN}$ patients with renal Clq deposition than without renal C1q deposition (31).

Autoantibodies against Clq were originally detected against the collagen-like tail region of Clq. Recently we have shown that anti-Clq antibodies are 
Maria Radanova, Vishnya Stoyanova, Kamelia Bratoeva et al.

generated also against the $\mathrm{A}, \mathrm{B}$ and $\mathrm{C}$ chains of the globular heads of C1q - anti-gC1q antibodies (20-22). We demonstrated that anti-Clq autoantibodies specifically against the globular domain of the ClqBchain from LN patient could partially induce acquired functional Clq deficiency and interfere with the biological function of Clq (22).

In this study we explored the associations between the presence of anti-Clq and anti-gClq antibodies and the levels of complement proteins $(\mathrm{Clq}$, C4, C3) to evaluate the potential pathological effects of anti-gClq antibodies and especially the effects of anti-B-gClq antibodies in LN. Interestingly, we found significantly lower serum C4 and C3 levels in patients positive for anti-B-gClq antibodies in comparison to patients positive for anti-A and anti-CgClq antibodies. The levels of $\mathrm{C} 3$ in patients seropositive for anti-B-gClq antibodies were also lower than the $\mathrm{C} 3$ levels in patients positive for anti-Clq antibodies (Fig. 2). Julkunen et al., (2012) found that anti-Clq antibodies and complement $\mathrm{C} 3$ and $\mathrm{C} 4$ were better markers for lupus nephritis activity than antidsDNA antibodies (32). Significant correlations were also observed for anti-C1q and anti-B-gClq antibodies to IgG CICs and to some other renal pathological characteristics in lupus nephritis (unpublished data). Low levels of C1/or C1q, C4 and C3 in the sera positive for anti-B-gClq autoantibodies patients could be an important correlation indicator for a possible crucial role of anti-B-gClq antibodies in the initiation of autoimmune response. Stoyanova et al., (2012) suggested that the presence of anti-gClq in both healthy and diseased humans also implied that these antibodies, unlike anti-CLR, might have a contribution to an onset of autoimmunity (33).

Thus, the population of polyclonal anti-Clq antibodies, which is very heterogeneous may influence on the immune response multidirectionally and to trigger autoimmunity, with severe pathological consequences.

\section{CONCLUSIONS}

Our findings and analyses suggest that the anti-gClq autoantibodies upon interaction and binding to Clq may trigger mechanical stress and structural conformational changes within the CLR domain of C1q, compatible with C1r-C1s activation in fluid phase. This complement activation results to onset of a strong inflammatory response, tissue deposition of immune complexes, triggering of apoptosis, necrosis and autoimmunity.

\section{ACKNOWLEDGMENTS}

We are grateful to Dr. Uday Kishore for providing the clones, expressing the recombinant analogues of the globular fragments of $A, B$ and $C$ chains of C1q. This work was supported by a grant DO-0217/03.12.2008 RILA-4, of the National Science Fund, Bulgarian Ministry of Education and Science.

\section{RERERENCES}

1. Siegert CE, Daha MR, Tseng CM, Coremans IE, van Es LA, Breedveld FC. Predictive value of IgG utoantibodies against Clq for nephritis in systemic lupus erythematosus. Ann Rheum Dis. 1993;52:851-6.

2. Trendelenburg M, Courvoisier S, Spath PJ, Moll S, Mihatsch M, Itin P, et al. Hypocomplementemic urticarial vasculitis or systemic lupus erythematosus? Am J Kidney Dis. 1999;34:745-51.

3. Horvath L, Czirjak L, Fekete B, Jakab L, Pozsonyi T, Kalabay L, et al. High levels of antibodies against $\mathrm{Clq}$ are associated with disease activity and nephritis but not with other organ manifestations in SLE patients. Clin Exp Rheumatol. 2001;19:667-72.

4. Moroni G, Trendelenburg M, Del Papa N, Quaglini S, Raschi E, Panzeri P, et al. Anti-Clq antibodies may help in diagnosing a renal flare in lupus nephritis. Am J Kidney Dis. 2001;37:490-8.

5. Gunnarsson I, Sundelin B, Heimburger M, Forslid J, van Vollenhoven R, Lundberg I, et al. Repeated renal biopsy in proliferative lupus nephritis-predictive role of serum Clq and albuminuria. J Rheumatol. 2002;29:693-9.

6. Marto N, Bertolaccini ML, Calabuig E, Hughes GR, Khamashta MA. Anti-Clq antibodies in nephritis: correlation between titres and renal disease activity and positive predictive value in systemic lupus erythematosus. Ann Rheum Dis. 2005;64:444-8.

7. Trendelenburg M, Lopez-Trascasa M, Potlukova E, Moll S, Regenass S, Fremeaux-Bacchi V, et al. High prevalence of anti-Clq antibodies in biopsy-proven active lupus nephritis. Nephrol Dial Transplant. 2006;21:3115-21.

8. Fang QY, Yu F, Tan Y, Xu LX,Wu LH, Liu G, et al. Anti-Clq antibodies and IgG subclass distribution 
in sera from Chinese patients with lupus nephritis. Nephrol Dial Transplant. 2009;24:172-8.

9. Mok CC, Ho LY, Leung HW, Wong LG. Performance of anti-Clq, antinucleosome, and anti-dsDNA antibodies for detecting concurrent disease activity of systemic lupus erythematosus. Transl Res. 2010;156:320-5.

10. Akhter E, Burlingame RW, Seaman AL, Magder L, Petri M. Anti-Clq antibodies have higher correlation with flares of lupus nephritis than other serum markers. Lupus 2011;20:1267-74.

11. Zhang CQ, Ren L, Gao F, Mu FY, You YQ, Liu YH. Anti-Clq antibodies are associated with systemic lupus erythematosus disease activity and lupus nephritis in northeast of China. Clin Rheumatol. 2011;30:967-73.

12. Kishore U, Gaboriaud C, Waters P, Shrive AK, Greenhough TJ, Reid KB, et al. Clq and tumor necrosis factor superfamily: modularity and versatility. Trends Immunol. 2004;25:551-61.

13. Roumenina LT, Ruseva MM, Zlatarova A, Ghai R, Kolev M, Olova Nq et al. Interaction of Clq with IgG1, C-reactive protein and pentraxin 3: mutational studies using recombinant globular head modules of human Clq A, B, and C chains. Biochemistry 2006;45:4093-04.

14. Roumenina LT, Popov KT, Bureeva SV, Kojouharova $\mathrm{M}$, Gadjeva $\mathrm{M}$, Rabheru S, et al. Interaction of the globular domain of human Clq with Salmonella typhimurium lipopolysaccharide. Biochim Biophys Acta. 2008;1784:1271-6.

15. Nayak A, Ferluga J, Tsolaki AG, Kishore U. The non-classical functions of the classical complement pathway recognition subcomponent Clq. Immunol Letters. 2010;131:139-50.

16. Nayak A, Pedenekar L, Reid KB, Kishore U. Complement and non-complement activating functions of Clq: a prototypical innate immune molecule. Innate Immun. 2012;18:350-63.

17. Kishore U, Gupta SK, Perdikoulis MV, Kojouharova MS, Urban BC, Reid KB. Modular organization of the carboxyl-terminal, globular head region of human Clq A, B, and C chains. J Immunol. 2003;171:812-20.

18. Siegert CE, Kazatchkine MD, Sjoholm A, Wurzner R, Loos M, Daha MR. Autoantibodies against Clq: view on clinical relevance and pathogenic role. Clin Exp Immunol. 1999;116:4-8.
19. Schaller M, Bigler C, Danner D, Ditzel HJ, Trendelenburg M. Autoantibodies against C1q in Systemic Lupus Erythematosus are antigen-driven. J Immunol. 2009;183:8225-31.

20. Deliyska B, Tsacheva I, Radanova M, Stoianova V, Tchorbadjieva M, Dobreva N. Lupus nephritis sera contain autoantibodies that recognize epitopes within the globular fragment of Clq. Med Pregl. 2007;60:25-7.

21. Tsacheva I, Radanova M, Todorova N, Argirova T. Kishore U. Detection of autoantibodies against the globular domain of human C1q in the sera of systemic lupus erythematosus patients. Mol Immuno. 2007;44:2147-51.

22. Radanova M, Vasilev V, Deliyska B, Kishore U, Ikonomov V, Ivanova D. Anti-Clq autoantibodies specific against the globular domain of the $\mathrm{ClqB}$ chain from patient with lupus nephritis inhibit Clq binding to IgG and CRP. Immunobiology 2012;217 684-91.

23. Hochberg MC. Updating the American College of Rheumatology revised criteria for the classification of systemic lupus erythematosus. Arthritis Rheum. 1997;40:1725.

24. Kazatchkine M, Hauptmann G, Nydegger U. Techniques du complement. Paris: INSERM 1985.

25. Radanova M, Tsacheva I, Argirova T, Kojouharova MS. Interaction of recombinant globular head regions of $\mathrm{Clq}$ with normal and autoimmune sera. Annulare de I'Universite de Sofia 'St. Kliment Ohridski', Faculte de biologie 2005;4:17-24.

26. Coremans IE, Spronk PE, Bootsma H, Daha MR, van der Voort EA, Kater L, et al. Changes in antibodies to Clq predict renal relapses in systemic lupus erythematosus. Am J Kidney Dis. 1995;26:595-601.

27. Katsumata Y, Miyake K, Kawaguchi Y, Okamoto Y, Kawamoto M, Gono T, et al. Anti-Clq antibodies are associated with systemic lupus erythematosus global activity but not specifically with nephritis: a controlled study of 126 consecutive patients. Arthritis Rheum. 2011;63:2436-44.

28. Trad B, Ben Hassine H, Khalifa M, Idriss N, Slama F, Bahri F, et al. Anti-Clq antibodies and systemic lupus erythematosus in the Tunisian population. Pathol Biol (Paris) 2013;61:113-6.

29. Flierman R, Daha MR. Pathogenic role of anti-Clq autoantibodies in the development of lupus nephritis - a hypothesis. Mol Immunol. 2007;44:133-8. 
30. Siegert C, Daha M, Westedt ML, van der Voort E, Breedveld F. IgG autoantibodies against Clq are correlated with nephritis, dermatitis, hypocomplementemia, and dsDNA antibodies in systemic lupus erythematosus. J Rheumatol. 1991;18:230-4.

31. Chen PC, Wang CR, Liu MF, Chen FF, Liang CC. Correlation between the renal $\mathrm{Clq}$ deposition and serum anti-C1q antibody: a potential role of antiClq antibody in lupus nephritis. Asian Pac J Allergy Immunol. 2002;20:223-27.

32. Julkunen H., Ekblom-Kullberg S., Miettinen A. Nonrenal and renal activity of systemic lupus erythematosus: a comparison of two anti-Clq and Wve anti-dsDNA assays and complement C3 and C4. Rheumatol Int. 2012;32:2445-51.

33. Stoyanova V, Tchorbadjieva M, Deliyska B, Vasilev $\mathrm{V}$, Tsacheva I. Biochemical analysis of the epitope specificities of anti-C1q autoantibodies accompanying human lupus nephritis reveals them as a dynamic population in the course of the disease. Immunol Lett. 2012;148:69-76. 